\title{
Detection of Replicative Intermediates of Hepatitis C Viral RNA in Liver and Serum of Patients with Chronic Hepatitis C
}

\author{
Tse-Ling Fong," Michiko Shindo, * Stephen M. Feinstone," Jay H. Hoofnagle, * and Adrian M. Di Bisceglie* \\ ${ }^{*}$ Liver Diseases Section, National Institute of Diabetes and Digestive and Kidney Diseases, National Institutes of Health, \\ Bethesda, Maryland 20892; and ${ }^{\ddagger}$ Center for Biologic Evaluation and Research, Division of Virology, \\ Hepatitis Research Laboratory, Food and Drug Administration, Rockville, Maryland 20895
}

\begin{abstract}
The hepatitis $\mathrm{C}$ virus is a positive stranded hepatotropic RNA virus. We describe a method of detecting positive and negative strands of hepatitis $C$ viral RNA using the polymerase chain reaction. We tested serum and liver tissue from nine patients with chronic hepatitis $C$. The positive RNA strand of $\mathrm{HCV}$ was detected in the sera and livers of all nine, the negative strand was detected in the livers of eight (89\%), and in the sera of five (55\%).

Titers of both strands of HCV RNA were determined by serial endpoint dilutions. The amount of the negative strand in the serum and liver was usually 10-100 times less than the positive strand. Predigestion of serum with ribonucleases did not alter the detection of the negative strand. This suggests that the negative strand found in the serum may be protected from digestion by being associated with virions. (J. Clin. Invest. 1991. 88:1058-1060.) Key words: polymerase chain reaction - hepatitis $\mathrm{C}$ replication

\section{Introduction}

Hepatitis $\mathrm{C}$ virus (HCV) ${ }^{1}$ is a positive-stranded RNA virus responsible for most cases of blood-borne non-A, non-B hepatitis. Although the genome of the virus has been cloned and its nucleotide sequence determined, little is known about its mechanism of replication. The HCV is closely related to the flaviviruses and pestiviruses (1) whose replicative strategies have been studied in vitro (2). Replication of flaviviruses involves the production of a complementary genomic-length negative RNA strand via semiconservative RNA synthesis using the positive RNA strand as a template. Positive strands are then amplified using the negative strand as a template (3). Positive strands produced in this way may be used to synthesize more negative RNA strands, to translate viral proteins or to be packaged into virions. The fate of the negative strand after completion of this cycle is not known.
\end{abstract}

Address correspondence to Tse-Ling Fong, M.D., Liver Diseases Section, NIDDK, NIH, Building 10, Room 4D52, Bethesda, MD 20892. 1991.

Received for publication 19 April 1991 and in revised form 28 May

1. Abbreviations used in this paper: $\mathrm{HCV}$, hepatitis $\mathrm{C}$ virus; $\mathrm{RT}$, reverse transcription.

The Journal of Clinical Investigation, Inc.

Volume 88, September 1991, 1058-1060
Due to the relatively small quantities of HCV-RNA found in serum and liver tissue of infected individuals, it can usually only detected by using the polymerase chain reaction (PCR) (4-10). We have studied the replication of HCV by determining the presence of the negative RNA strand of HCV in the serum and liver of infected patients. PCR does not selectively detect either the positive or negative strands of $\mathrm{HCV}$, as it is usually performed. We describe the specific detection of both the negative (replicative) RNA strand and the positive (genomic) RNA strand, separately, in the serum and liver tissue of infected individuals. The relative quantities of the positive and negative strands were determined and compared by serial end point dilutions.

\section{Methods}

Paired liver biopsy and serum samples were obtained from nine patients with chronic hepatitis $C$ who were being evaluated for various trials of antiviral therapy. A portion of the liver biopsy was immediately frozen in liquid nitrogen and stored at $-70^{\circ} \mathrm{C}$ until use. Serum samples were obtained on the same day and stored at $-20^{\circ} \mathrm{C}$. AntiHCV was assayed by ELISA (Ortho Diagnostics, Raritan, NJ).

RNA was extracted from liver as described by Chomczynski and Sacchi with several modifications (11). Briefly, the frozen tissue (wt, $\sim 20-30 \mathrm{mg}$ ) was homogenized in $450 \mu \mathrm{l} 4 \mathrm{M}$ guanidinium thiocyanate, $2 \mathrm{mM}$ sodium citrate, $\mathrm{pH} 7,5 \%$ sarcosyl, and $0.1 \mathrm{M}$ mercaptoethanol. Sequentially, $45 \mu \mathrm{l}$ of $2 \mathrm{M}$ sodium acetate ( $\mathrm{pH} \mathrm{4),} 450 \mu \mathrm{l}$ watersaturated phenol, and $300 \mu \mathrm{l}$ chloroform-isoamyl alcohol mixture (49:1) were added and mixed. The suspension was placed on ice for 15 min and then centrifuged at $10,000 \mathrm{~g}$ for $20 \mathrm{~min}$. The aqueous layer was then extracted with an equal volume of chloroform and alcohol precipitated overnight. The RNA pellet was washed in $70 \%$ ethanol, and resuspended in RNasin-treated autoclaved water $\left(200 \mathrm{U} / \mathrm{ml} \mathrm{H}_{2} \mathrm{O}\right)$ (Promega Biotec, Madison, WI). The amount of RNA extracted from liver was determined by spectrophotometry. RNA from serum was extracted from $50 \mu \mathrm{l}$ serum in guanidinium thiocyanate, phenol/chloroform as previously described (12). The precipitate was dissolved in 80 $\mu \mathrm{l}$ of RNase free water.

The positive and negative strands of viral RNA were detected by performing reverse transcription of RNA samples in the presence of only one oligonucleotide primer (either the sense or the antisense primer) followed by heat inactivation of the reverse transcriptase. The DNA made in this reverse transcription reaction was therefore complementary to one or the other RNA strand and could then be amplified by PCR in the presence of both oligonucleotide primers.

The oligonucleotide primers used were chosen from the highly conserved 5 ' noncoding region nucleotide sequence of the HCV genome (13). For the external primers the following sequences were used: sense, nucleotide Nos. 1-21, 5'-GGCGACACTCCACCATAGATC-3' and antisense, nucleotide Nos. 304-324, 5'-GGTGCACGGTCTACGA- 
GACCT-3'. The internal primers were as follows: sense, nucleotide Nos. 28-48, 5'-CTGTGAGGAACTACTGTCTTC-3' and antisense, nucleotide Nos. 264-284, 5'-CCCTATCAGGCAGTACCACAA-3'.

Reverse transcription (RT) was performed as described by Kawasaki (14) in a $20 \mu l$ reaction volume containing $5 \mu$ l of either liver (1.5 $\mu \mathrm{g}$ total RNA) or serum RNA, $0.2 \mu \mathrm{M}$ of either the sense or antisense primers, $200 \mu \mathrm{M}$ of the four dNTP (Promega Biotec), $20 \mathrm{U}$ of RNasin (Promega Biotec), $1 \times$ PCR buffer and $5 \mathrm{U}$ of AMV reverse transcriptase (Promega Biotec). The mixture was overlaid with mineral oil and incubated at $42^{\circ} \mathrm{C}$ for $30 \mathrm{~min}$. The reverse transcriptase was then inactivated by heating at $95^{\circ} \mathrm{C}$ for $20 \mathrm{~min}$ and then quickly chilled on ice.

PCR amplification was performed by adding $80 \mu l$ of $1 \times$ PCR buffer containing $0.2 \mu \mathrm{M}$ of the opposite sense primer and $2 \mathrm{U}$ of Taq polymerase (Perkin Elmer Cetus, Norwalk, CT). The thermocycler was programmed to incubate samples at $95^{\circ} \mathrm{C}$ for $5 \mathrm{~min}$ and then to carry out 25 cycles consisting of $95^{\circ} \mathrm{C}$ for $30 \mathrm{~s}, 55^{\circ} \mathrm{C}$ for $1 \mathrm{~min}$ and $72^{\circ} \mathrm{C}$ for 1 min, followed by a 5 -min final extension at $72^{\circ} \mathrm{C}$.

For the second amplification, $10 \mu \mathrm{l}$ were removed from the first reaction and were added to a similar reaction mixture as the first with $0.2 \mu \mathrm{M}$ of the inner primers instead of the outer primers. PCR was carried out for 35 cycles as described for the first amplification.

$20 \mu \mathrm{l}$ of the second amplification was analyzed by electrophoresis in a $2 \%$ agarose gel containing $0.5 \mu \mathrm{g} / \mathrm{ml}$ of ethidium bromide, and visualized under ultraviolet light. The size of the expected amplification product was $257 \mathrm{bp}$. Titers of HCV-positive and -negative strand RNA were estimated by testing 10-fold serial dilutions of RNA extracted from 50 $\mu$ l of serum.

Carryover PCR contamination was avoided by following the measures outlined by Kwok and Higuchi (15). All serum and liver samples were extracted in parallel with negative controls, which included three liver samples from patients with chronic hepatitis B, one from a patient with systemic mastocytosis and two normal liver samples.

For each set of reverse transcription/PCR experiments, a series of controls were performed. To exclude contamination by a PCR product, a reaction was performed using all the components except RT. This control reaction would also rule out the possibility of a replicative DNA intermediate. To rule out residual RT activity after heat inactivation of RT, a reaction was done using all components except the primer during the RT step. After heat inactivation of RT, both sense and antisense primers were included in the PCR mixture. To rule out contamination of the outer sense primer with the antisense primer, the RT reaction and first PCR was carried out using only the sense primer.

\section{Results}

Liver and serum from nine patients with chronic hepatitis $C$ were analyzed. All patients had elevated serum aminotransferase activities (mean serum alanine aminotransferase $157 \mathrm{U} /$ liter, range 86-409 U/liter, normal < $41 \mathrm{U} /$ liter) for $>6 \mathrm{mo}$. All had antibodies to $\mathrm{HCV}$ in serum. Histological examination of their liver biopsy samples showed chronic active hepatitis in eight and active cirrhosis in one (Table I).

The positive RNA strand of $\mathrm{HCV}$ was detected in the liver of all nine patients $(100 \%)$ (geometric mean titer, $10^{-3.2}$; range, $10^{-2}-10^{-5}$ ) and the negative strand was found in eight of the nine patients $(89 \%)$. The titer of the negative RNA strand of $\mathrm{HCV}$ in the liver was 10-100 times less than the positive strand (Table I).

The positive RNA strand of HCV was detected in the serum of nine patients $(100 \%)$ (geometric mean titer, $10^{-2.7}$; range, $\left.10^{-1}-10^{-4}\right)$. The negative strand was detected in only five of the nine patients $(56 \%)$. The titer of the negative strand was 10 -fold less than the positive strand in four patients and the same in one patient. The presence of the negative strand in the serum did not correlate with the presence or the titer of the negative strand in the liver. The presence or the titer of the negative strand did not correlate with the aminotransferase activities or the severity of the histology (Table I).

Neither strand of HCV RNA was found in the negative control samples. Control reactions in which RT was either destroyed before the addition of primers, or not added, were all negative. Reactions using only one set of primer (sense primer) were negative.

To determine whether the negative RNA strand of HCV in the serum was free or protected from serum nucleases, serum from three patients containing high titers of the negative strand was subjected to ribonuclease digestion before extraction of RNA as follows. Sera were incubated with a mixture of RNase $\mathrm{A}(1 \mathrm{mg} / \mathrm{ml})$ and RNase T1 $(20,000 \mathrm{U} / \mathrm{ml})$ (Ambion, Austin, $\mathrm{TX})$ at $37^{\circ} \mathrm{C}$ for $30 \mathrm{~min}$. No change was seen in either the amount or character of both negative and positive strand $\mathrm{HCV}$

Table I. Demographic, Biochemical, and Histological Characteristics of the Nine Patients with Chronic Hepatitis C and Titers of Positive and Negative RNA Strands of HCV in Liver and Serum

\begin{tabular}{|c|c|c|c|c|c|c|c|c|}
\hline \multirow[b]{2}{*}{ No. } & \multirow{2}{*}{$\begin{array}{c}\text { Age/sex/ } \\
\text { race }\end{array}$} & \multirow[b]{2}{*}{ Source } & \multirow[b]{2}{*}{ ALT } & \multirow[b]{2}{*}{ Histo } & \multicolumn{2}{|c|}{ Liver strand } & \multicolumn{2}{|c|}{ Serum strand } \\
\hline & & & & & Pos & Neg & Pos & Neg \\
\hline & & & & & titer & titer & titer & titer \\
\hline 1 & $38 / F / W$ & IVDA & 109 & seCAH & $10^{-3}$ & $10^{-2}$ & $10^{-3}$ & neg \\
\hline 2 & $41 / F / W$ & IVDA & 101 & seCAH & $10^{-3}$ & $10^{-1}$ & $10^{-3}$ & $10^{-3}$ \\
\hline 3 & $33 / \mathrm{M} / \mathrm{W}$ & PT & 140 & miCAH & $10^{-2}$ & $10^{-1}$ & $10^{-2}$ & $10^{-1}$ \\
\hline 4 & $38 / \mathbf{M} / \mathbf{W}$ & NS & 254 & $\mathrm{miCAH}$ & $10^{-5}$ & $10^{-3}$ & $10^{-4}$ & $10^{-3}$ \\
\hline 5 & $43 / \mathrm{M} / \mathrm{W}$ & PT & 150 & acCIRR & $10^{-4}$ & $10^{-3}$ & $10^{-3}$ & neg \\
\hline 6 & 48/M/B & spor & 163 & moCAH & $10^{-2}$ & neg & $10^{-2}$ & neg \\
\hline 7 & $43 / F / W$ & IVDA & 409 & moCAH & $10^{-3}$ & $10^{-1}$ & $10^{-2}$ & neg \\
\hline 8 & $50 / \mathrm{M} / \mathrm{B}$ & spor & 103 & seCAH & $10^{-3}$ & $10^{-3}$ & $10^{-1}$ & $10^{\circ}$ \\
\hline 9 & $27 / F / W$ & IVDA & 86 & miCAH & $10^{-4}$ & $10^{-3}$ & $10^{-4}$ & $10^{-3}$ \\
\hline
\end{tabular}

ALT, alanine aminotransferase; F, female; M, male; IVDA, intravenous drug abuse; PT, posttransfusion; NS, needlestick injury; spor, sporadic; $\mathrm{CAH}$, chronic active hepatitis; mi, mo, se, mild, moderate, or severe; acCirr, active cirrhosis; neg, negative. 
cDNA after reverse transcription and PCR. To assess the efficiency of ribonuclease digestion of free viral RNA, RNA was extracted from serum of patients 4 and 9 (see Table I) and added to normal serum with and without the addition of ribonucleases before performing RT-PCR. Under these conditions, the HCV RNA from both patients was completely degraded by the ribonucleases.

\section{Discussion}

Choo and co-workers originally suggested that the HCV was a positive-stranded RNA virus based on hybridization studies of RNA extracted from the serum of an infected chimpanzee (1). They found that the cDNA strand from their original clone of $\mathrm{HCV}$ that hybridized to plasma-derived RNA was complementary to the strand encoding a recombinant $\mathrm{HCV}$ protein, indicating that the HCV RNA found in serum was positivestranded with respect to the translation of this protein.

Little has been learned subsequently about the replicative strategy of HCV. Because of the relatively small amounts of HCV present in liver and serum, HCV RNA cannot be reliably detected by standard molecular hybridization techniques. Using a modification of the PCR technique, we have been able to separately identify and quantitate both positive and negative strands of HCV RNA in samples from patients with chronic $\mathrm{HCV}$ infection.

The presence of the positive (genomic) RNA strand in the liver was confirmed and, in addition, we demonstrated the presence of the negative (replicative) RNA strand of HCV within the liver. This suggests that the HCV replicates via a negativestranded RNA intermediate. The amount of the negative HCV RNA strand was usually at least 10 -fold less than the positive strand, a ratio that was described in a study of RNA synthesis in type 2 Dengue virus in cell culture (3). The absence of a DNA replicative intermediate was confirmed by the control reaction in which extracted nucleic acids were amplified without prior RT (1)

Whereas the finding of the negative RNA strand of HCV in the liver was not unexpected, its presence in serum in some patients was surprising. The reason for the presence of the negative RNA strand of HCV in serum remains to be determined. The observation that both positive and negative RNA strands in serum were resistant to digestion by ribonucleases suggests that they are both virion associated. Another possibility is that the negative RNA strand of HCV could also be membranebound but not virion-associated and be released during hepatocytolysis, thus protecting it from ribonuclease digestion. Finally, it is possible that the negative RNA strand of HCV was present in serum in free form after its release from the liver by hepatocytolysis induced by HCV infection. This explanation appears unlikely as we found that free HCV RNA which had been extracted from virions and added to serum was digested and rendered undetectable by ribonuclease treatment.

The clinical significance of finding the negative RNA strand of $\mathrm{HCV}$ in liver or serum remains to be determined, as its presence was not associated with higher serum aminotransferase activities or more severe liver disease histologically (Table I). Similarly, the levels of HCV RNA in the liver do not appear to be related to the degree of liver injury present although only a relatively small number of patients were studied. Previous studies have found that a clinical and biochemical response to alpha interferon therapy in patients with chronic hepatitis $\mathrm{C}$ was associated with the disappearance of $\mathrm{HCV}$ genome from serum. However, HCV RNA invariably reappeared in patients in whom the hepatitis relapsed when interferon was stopped (12). The presence or absence of hepatic HCV RNA (both positive and negative strands) may be a useful marker of response to antiviral therapy, in particular, to evaluate the appropriate timing for discontinuation of therapy.

\section{References}

1. Choo, Q. -L., G. Kuo, A. J. Weiner, L. R. Overby, D. W. Bradley, and M. Houghton. 1989. Isolation of a cDNA clone derived from a blood-borne non-A non-B viral hepatitis genome. Science (Wash. DC). 244:359-362.

2. Chambers, T. J., C. S. Hahn, R. Galler, and C. M. Rice. 1990. Flavivirus genome organization, expression, and replication. Annu. Rev. Microbiol. 44:649688.

3. Cleaves, G. R., T. E. Ryan, and R. W. Schlesinger. 1981. Identification and characterization of type 2 Dengue virus replicative intermediate and replicative form RNAs. Virology. 111:73-83.

4. Weiner, A. J., G. Kuo, D. W. Bradley, F. Bonino, G. Saracco, C. Lee, J. Rosenblatt, Q.-L. Choo, and M. Houghton. 1990. Detection of hepatitis C viral sequences in non-A, non-B hepatitis. Lancet. 355:1-3.

5. Garson, J. A., R. S. Tedder, W. Briggs, P. Tuke, J. A. Glazenbrook, A. Trute, D. Parker, J. A. J. Barbara, M. Contreras, and S. Aloysius. 1990. Detection of hepatitis C viral sequences in blood donations by "nested" polymerase chain reaction and prediction of infectivity. Lancet. 335:1419-1422.

6. Okamoto, H., S. Okada, Y. Sugiyama, T. Tanaka, Y. Sugai, Y. Akahane, A Machida, S. Mishiro, H. Yoshizawa, Y. Miyakawa, and M. Mayumi. 1990. Detection of hepatitis $\mathbf{C}$ virus RNA by a two-stage polymerase chain reaction with two pairs of primers deduced from the 5 ' noncoding region. Jpn. J. Exp. Med. 60:315-322.

7. Kaneko, S., M. Unoura, K. Kobayashi, K. Kuno, S. Murakami, and N. Hattori. 1990. Detection of serum hepatitis C virus RNA. Lancet. 335:976.

8. Ulrich, P. P., J. M. Romeo, P. K. Lane, I. Kelly, L. J. Daniel, and G. N. Vyas. 1990. Detection, semiquantitation, and genetic variation in hepatitis $C$ virus sequences amplified from the plasma of blood donors with elevated alanine aminotransferases. J. Clin. Invest. 86:1609-1614.

9. Kato, N., O. Yokosuka, M. Omata, K. Hosoda, and M. Ohto. 1990. Detection of hepatitis $\mathrm{C}$ virus ribonucleic acid in the serum by amplification with polymerase chain reaction. J. Clin. Invest. 86:1764-1767.

10. Simmonds P., L. Q. Zhang, H. G. Watson, S. Rebus, E. D. Ferguson, P. Balfe, G. H. Leadbetter, P. L. Yap, J. F. Peutherer, and C. Ludlam. 1990. Hepatitis $\mathrm{C}$ quantification and sequencing in blood products, hemophiliacs, and drug users. Lancet. 336:1469-1472.

11. Chomczynski, P., and N. Sacchi. 1987. Single-step method of RNA isolation by acid guanidinium thiocynate-phenol-chloroform extraction. Anal. Biochem. 162:156-159.

12. Shindo, M., A. M. Di Bisceglie, L. Cheung, J. W.-K. Shih, B. Baker, S. M. Feinstone, K. Cristiano, and J. H. Hoofnagle. 1990. Changes in hepatitis C viral RNA in serum with alpha interferon therapy. Hepatology (Baltimore). 12:884. (Abstr.)

13. Okamoto, H., S. Okada, Y. Sugiyama, S. Yotsumoto, T. Tanaka, H. Yoshizawa, F. Tsuda, Y. Miyakawa, and M. Mayumi. 1990. The 5'-terminal sequence of the hepatitis C virus genome. Jpn. J. Exp. Med. 60:167-177.

14. Kawasaki, E. S. 1990. Amplification of RNA. In PCR Protocols. A Guide to Methods and Applications. M. Innis, D. Gelfand, J. Sninsky, and T. White editors. Academic Press, Inc., San Diego. 21-27.

15. Kwok, S., and R. Higuchi. 1989. Avoiding false positives with PCR. Nature (Lond.). 339:237-238. 